\title{
Does Terrorism Demoralize? Evidence from Israel ${ }^{*}$
}

\author{
Asaf Zussman ${ }^{\dagger}$ \\ Department of Economics \\ Cornell University
}

\author{
Noam Zussman \\ Research Department \\ Bank of Israel
}

May 4, 2007

\author{
Dmitri Romanov \\ Central Bureau of Statistics \\ Israel
}

\begin{abstract}
Terrorism is a form of psychological warfare which aims to achieve political goals through the use of violence. We study the effect of Palestinian terrorism on the life satisfaction (happiness) of Israelis during the recent Intifada. The analysis relies on detailed daily data on terrorism and on daily responses to a subjective life satisfaction question recorded in social surveys conducted in Israel in 2002-2004. Our analysis controls for important determinants of happiness identified in the literature but adds to them daily fatality figures which capture the intensity of terrorism. The main finding of our analysis is that Palestinian terrorism has had practically no effect on the happiness of Israelis. Overall, the level of happiness remained stable throughout the Intifada years despite a large variation in the intensity of terrorism across time and location. The evidence thus casts a doubt on the effectiveness of terrorism in achieving one of its main objectives - demoralizing enemy population.
\end{abstract}

JEL classification codes: H56, I31

Keywords: Terrorism, Happiness, Life Satisfaction, Israel

\footnotetext{
${ }^{*}$ We are indebted to participants of a seminar at Cornell University and to Alan Krueger for useful comments.

${ }^{\dagger}$ Corresponding author. Please address correspondence to: Asaf Zussman, Department of Economics, Cornell University, 480 Uris Hall, Ithaca, NY 14853; Phone: (607) 255-2355; E-mail: azussman@cornell.edu
} 


\section{Introduction}

Terrorism involves the use of violence in order to attain political goals. A key feature of terrorism is that it is specifically designed to have far-reaching psychological effects beyond the immediate victims or objects of the terrorist attacks. Terrorism is thus a sophisticated form of psychological warfare which aims to achieve political ends by influencing individuals' emotions and attitudes (Friedland and Merari, 1985). In this paper we focus on Palestinian terrorism during the Intifada which broke out in the fall of 2000 and claimed the lives of more than a thousand Israelis. This period saw the widespread use of suicide terrorist attacks. As Hoffman (2006) argues, suicide terrorism was embraced by Palestinian terrorist organizations as an especially powerful psychological weapon in order to demoralize the Israeli population.

We examine whether Palestinian terrorism achieved this goal by studying the self-reported happiness of Israelis. The analysis relies on detailed daily data on terrorism and on responses to a subjective life satisfaction question recorded in comprehensive Social Surveys conducted in Israel in 2002-2004, during the Intifada. We were able to obtain the date, the time, and the location in which each of the survey interviews was conducted. This information provided a link to our detailed daily data on terrorism. ${ }^{1}$

Our analysis controls for important determinants of happiness identified in the literature - such as age, health, education, and religiosity - but adds to them daily fatality figures which capture the intensity of terrorism. ${ }^{2}$ We argue that terrorism can have both a direct and an indirect effect on happiness. The indirect effect comes about through terrorism-induced deterioration in economic circumstances. ${ }^{3}$ By including in our regressions variables like income and unemployment status we control for this indirect effect. The focus of our analysis is on the direct effect, which is captured by the influence of terrorism fatalities on the responses of survey participants to the life satisfaction question.

To our knowledge the only other study that estimates the influence of terrorism on happiness is Frey et al. (2004). ${ }^{4}$ The study uses data on terrorism and life satisfaction (from the Eurobarometer) for France, the United Kingdom, and the Republic of Ireland from 1973 to 1998. For each country

\footnotetext{
${ }^{1}$ It is important to note that in this study we include under the heading "terrorism" attacks which resulted in both civilian and security forces fatalities, although some of the latter attacks would not be considered acts of terrorism in some formal definitions. As we show below, our results are robust to focusing on civilian fatalities only.

${ }^{2}$ Recent updates on the state of the happiness literature can be found in Frey and Stutzer (2005), DiTella and MacCulloch (2006), and Kahneman and Krueger (2006).

${ }^{3}$ Previous research has estimated that the cumulative GDP loss in Israel due to the Intifada was in the region of 10 percent. See, for example, Eckstein and Tsiddon (2004) and Zussman and Zussman (2006).

${ }^{4}$ Condensed versions of these results appear in Frey and Stutzer (2005) and in Frey et al. (2007).
} 
the authors estimate a separate happiness equation which includes an annual measure of the intensity of terrorism in different regions of the country. The study finds that terrorism strongly depressed happiness. The authors estimate, for example, that "a resident of London would be willing to forego $32 \%$ of his income" to reduce terrorism to a level that prevails in the country's more peaceful parts.

We believe that our study has several advantages relative to Frey et al. (2004). First, we use high frequency (daily) data whereas they use low frequency (annual) data. The use of high frequency data allows us to get a relatively clean estimate of the immediate effect of terrorist attacks. Second, our data on terrorism is much more detailed. This enables us to explore a wide variety of issues, such as how the direction and strength of the reaction to terrorism depends on characteristics of the victims, characteristics of the survey participants, and the interaction between the two. Third, the intensity of terrorism in France and the United Kingdom - and during part of the period in the Republic of Ireland - was an order of magnitude less than what Israel experienced during the Intifada. ${ }^{5}$ From the narrow perspective of empirical analysis this gives our study an important advantage.

A line of research in psychology and psychiatry is also related to our analysis. Several studies have examined the effect of the terrorist attacks of September 11th, 2001 in the U.S. on symptoms of posttraumatic stress disorder (PTSD). Based on a survey conducted three to five days after the attacks Schuster et al. (2001) report that Americans across the country had substantial symptoms of stress. In contrast, based on a survey conducted one to two months after the attacks Schlenger et al. (2002) report that the overall psychological distress levels in the U.S. were within normal ranges. The same study reports, however, that the prevalence of PTSD in the New York City metropolitan area was substantially higher than elsewhere in the country. Galea et al. (2002) and Cohen Silver et al. (2002) also find that levels of PTSD were positively correlated with the severity of exposure to the attacks.

More relevant to our analysis are the studies that focus on the psychological effect of Palestinian terrorism on Israelis. Based on a survey conducted in April and May of 2002, at the height of the Intifada, Bleich et al. (2003) conclude that the psychological impact seems to be moderate. Surprisingly, they find that the level of exposure to terrorism was not associated with the incidence of PTSD. In a follow up study based on a survey conducted in May 2004, during a relatively calm period, Bleich et. al. (2006) report similar rates of PTSD as in the 2002 survey. Using data from a survey conducted from

\footnotetext{
${ }^{5}$ Frey et al. (2004) report, for example, that the average annual number of fatalities in Great Britain from the Northern Ireland conflict in 1975-1998 was 2.91. In contrast, the average annual number of fatalities in Israel from Palestinian terrorism in 2002-2004 was 262. This difference is compounded by the fact that Israel's population is much smaller than Great Britain's.
} 
June to August of 2001, Shalev et. al. (2006) compared rates of PTSD in residents of two suburbs of Jerusalem, with one being more directly affected by terrorism than the other. The study reports that the two groups showed comparable levels of PTSD.

The studies mentioned above are relevant to our analysis since mental health has been found to be strongly correlated with happiness. ${ }^{6}$ At the same time we believe that our study has several advantages relative to the literature in psychology and psychiatry. First, and most importantly, the studies mentioned above are based on surveys that explicitly focus on the psychological effect of terrorism. This may bias the results to the extent that people are prompted to think about the subject. In contrast, the life satisfaction data that we use is obtained from Social Surveys that do not mention the word terrorism. The connection between terrorism and subjective assessment of well-being was only established by us. Second, the surveys that we use contain a very large number of observations: we have around 22,000 while the typical study in psychology has less than 1,000. Our survey is also richer in terms of the number of respondent characteristics that may be used as controls in the analysis. Third, unlike the studies in psychology which paint a picture at a given point in time, our analysis relies on a continuous (daily) measurement of the outcome variable.

We begin our empirical analysis by demonstrating that at the annual and monthly frequencies the intensity of terrorism was uncorrelated with the overall happiness of Israelis. We also demonstrate that differences in exposure to terrorism across cities in Israel were not correlated with city-wide levels of happiness. Using Eurobarometer data we demonstrate that during the three years examined Israelis were not particularly unsatisfied with their lives when compared to citizens of other, mostly terrorismfree, countries.

Our main set of results is derived from estimating individual level happiness equations augmented with daily data on terrorism fatalities. We show that the number of country-wide terrorism fatalities has no direct same-day effect on the life satisfaction of Jewish Israelis. On the other hand, Arab citizens of Israel (Arab-Israelis) display a negative same-day reaction to terrorism fatalities, although this reaction does not persist for more than a day. We argue that the initial negative reaction of Arabs may be related to increasing concerns of discrimination against them. In further analyses we demonstrate that the lack of reaction of life satisfaction to terrorism is not due to habituation; that Jewish Israelis display a negative same-day reaction to civilian fatalities when the terrorist attack takes place in the survey respondent's own city; and that Arab-Israelis react negatively to civilian fatalities but not to security

\footnotetext{
${ }^{6}$ See, for example, Layard (2005). In section 3.3 below we provide independent evidence on the relationship between happiness and mental health.
} 
forces fatalities.

We believe that our study makes two important contributions, one methodological and the other substantive. The methodological contribution is in the application of an event-study style approach to the study of happiness. Using daily survey data - aggregated to weekly observations - Kimball et al. (2006) examine the influence of Hurricane Katrina (which struck New Orleans and the surrounding areas in August 2005) on the happiness of Americans. They find that the response of happiness was especially strong in the South Central region, closest to the devastation of Katrina. The dip in happiness lasted two or three weeks in that region and one or two weeks in the rest of the country. Methodologically, the major difference between that study and ours is the repeated nature of the exogenous shock examined in our case. We demonstrate that one can fruitfully use detailed high-frequency data on life satisfaction to study the effects of recurring unpredicted exogenous events.

The substantive contribution of our study lies in the examination of a previously under-studied but very important question of the effect of terrorism on morale. The evidence we present in this study casts a doubt on the effectiveness of terrorism in achieving one of its objectives - demoralizing the enemy population.

The rest of the study is organized as follows. In the next section we describe the data and the econometric methodology we employ. In section 3 we present the evidence on the effect of terrorism on happiness. At the end of this section we discuss and analyze potential explanations for our "non-result". Section 4 offers concluding remarks.

\section{Data and Methodology}

\subsection{Life satisfaction and terrorism data}

In 2002 Israel's Central Bureau of Statistics conducted its first Social Survey, which covered a representative sample of roughly 7,000 individuals aged 20 and older. The survey contained dozens of questions about the socio-demographic and economic characteristics of each individual's household. Since 2002 the survey has been repeated annually, each time with a different set of individuals. For our purposes the most relevant question in the survey is the one in which the surveyed individual is asked about his or her satisfaction with life. There are four possible answers to this question: "very satisfied", "fairly satisfied", "not very satisfied", and "not at all satisfied." The structure of the question and the possible answers are identical to those contained in other surveys of this type, such as the Eurobarometer. Our data is from the surveys of 2002, 2003, and 2004, which together covered around 22,000 individuals. The 
surveys are administered in person (at the respondent's residence) by employees of the Israeli Central Bureau of Statistics. They are typically conducted during weekdays (Sunday to Friday) in the afternoon hours. We were able to obtain the date, the time, and the location in which each of the surveys was conducted. This information provides a link to our data on terrorism.

The data on terrorism covers the same period as the Social Surveys and combines information from several sources: B'tselem, the Israeli Information Center for Human Rights in the Occupied Territories; The Israeli Ministry of Foreign Affairs; The Israeli Ministry of Defense; and the Israeli National Insurance Institute. Terrorism data obtained from these sources was cross-checked and augmented using media reports obtained via the LexisNexis service. This allows us to assign to each terrorism attack a date and an approximate time. In order to link this data to the surveys we used a cutoff rule: if the attack occurred after the survey was administered it would be assigned to the next survey date. The data on terrorism covers all politically motivated and fatal attacks inside Israel and in the Occupied Territories (Judea, Samaria, and the Gaza Strip). It includes attacks against both civilians and security forces. In each case we have information about the number of fatalities, location, and other relevant variables.

It is important to note that our ability to analyze life satisfaction on a daily basis rests on two features of the Israeli Social Survey: (1) the number of individuals surveyed is relatively large; (2) the survey is conducted throughout the year. To gain perspective it is useful to compare the Israeli Social Survey to the Eurobarometer. In 2004, for example, the Eurobarometer survey population (individuals aged 15 and older in EU-15 countries) was 304 million. Of them about 15,000 were surveyed. In the same year 7,616 Israelis were surveyed out of a population (individuals aged 20 and older) of about 4.2 million. Thus the Eurobarometer had only 5 surveys per 100,000 population while the Israeli Social Survey had 180. Moreover, the Eurobarometer survey is conducted only once or twice a year, and in each case lasts for only one month. In contrast the Israeli survey is conducted throughout the year, with an average of 23 interviews per day.

\subsection{Econometric methodology}

The four possible responses to the Social Survey question on life satisfaction can be ordered in a natural way: a person that is "very satisfied" is more satisfied than a person who is just "fairly satisfied" and so on. This implies that a natural way to econometrically analyze the determinants of life satisfaction is to use discrete choice models of ordered data, such as Ordered Logit. This is also the main approach we take. However, we also demonstrate that the same qualitative results are obtained by dividing the four possible responses to the life satisfaction question into two categories, satisfied (pulling together 
"very satisfied" and "fairly satisfied") and unsatisfied (pulling together "not very satisfied" and "not at all satisfied"), and using Logit instead of Ordered Logit. ${ }^{7}$

\section{Does Terrorism Demoralize? The Evidence}

\subsection{The big picture}

During 2002-2004 there were 785 terrorism fatalities in Israel, two thirds of them civilian (Table 1). Over time the terrorist threat diminished: the total number of fatalities dropped by half from 2002 to 2003 and again by half from 2003 to 2004. Although the terrorist threat declined over time, happiness remained stable (Table 2): the share of satisfied individuals (sum of top two rows) was 82.9 percent in 2002, 81.7 percent in 2003, and 82.4 percent in 2004 .

Figure 1A demonstrates that while there was significant month to month variation in the terrorism death toll during 2002-2004, satisfaction with life was relatively stable at around 82 percent. Casual inspection of Figure 1B strengthens the impression that the intensity of terrorism and life satisfaction were uncorrelated. Especially noteworthy is the fact that during the month with the largest number of fatalities (March 2002), the overall level of life satisfaction was higher than average.

In Table 3 we compare the life satisfaction of Israelis to that of residents of the EU-15 countries. We find that residents of Scandinavian countries are very much satisfied with their lives while residents of southern European countries are much less satisfied. Both results are well-documented in the literature. ${ }^{8}$ The life satisfaction of Israelis was similar to that of residents of the EU-15 countries. In 2002, the year with the highest number of terrorism fatalities, the satisfaction of Israelis with their lives was higher than the average of the EU-15 countries. In that year Israel was ranked 9 th in this group of 16 countries. Interestingly, as the number of terrorism fatalities in Israel decreased the relative ranking of the country in terms of life satisfaction actually dropped slightly. Overall, Table 3 strongly suggests that during the Intifada residents of Israel were not particularly unhappy when compared to residents of the relatively terrorism-free EU-15 countries. ${ }^{9}$

Is it the case that residents of Israeli cities that were subjected more intensely to terrorism less satisfied with their lives? We explore this issue in Figure 2, which plots aggregate life satisfaction against

\footnotetext{
${ }^{7}$ The results are also robust to the use of Ordered Probit and Probit. In all cases the estimation takes account of sampling weights.

${ }^{8}$ See, for example, Blanchflower and Oswald (2007).

${ }^{9}$ It is interesting to note that the large terrorist attack in Madrid on March 11, 2004 did not lower the life-satisfaction of Spaniards. In fact the share of satisfied individuals in Spain rose from 83 to 86 percent between 2003 and 2004.
} 
terrorism intensity in Israel's eight largest cities. ${ }^{10}$ Figure 2 seems to suggest a positive correlation between the two variables. It is especially striking that in Jerusalem, the city that suffered most from terrorism, satisfaction with life is the highest. One should not draw the conclusion that a particularly high level of terrorism made Jerusalem a happy place, however, since a large share of Jerusalem's Jewish residents are highly religious and religiosity is positively and strongly associated with life satisfaction (as we show in the next section). Thus controlling for a large set of potentially confounding factors is crucial in identifying the relationship between terrorism and happiness. We turn to such a micro-econometric examination next.

\section{$3.2 \quad$ A closer look}

Table 4 displays the results of our baseline life satisfaction equations. The set of baseline regressors we use is relatively standard in the happiness literature. The Ordered Logit results for Jewish Israelis reported in column 1 show that (all else being equal) males are more satisfied with their lives than females and that the effect of age on life satisfaction has the well documented U-shape. Married individuals are happier than the non-married. Life satisfaction rises with the number of children one has, the level of education, and with religiosity. Poor health is strongly negatively associated with life satisfaction as is being an immigrant.

Unsurprisingly, higher per-capita family income is associated with more satisfaction with life. Conversely, being unemployed strongly depresses life satisfaction. By including these two variables in the equation we control for what was termed in the introduction the "indirect effect of terrorism": the possibility that an individual suffered an adverse economic shock because of the Intifada.

The Ordered Logit results for Arab-Israelis, presented in column 2, are overall quite similar to those obtained for Jews. The main interesting exception is the finding that Arab females are more satisfied with their lives than Arab males. Table 4 suggests that the method of estimation does not matter: the Logit results in columns 3 and 4 are qualitatively identical to those obtained using Ordered Logit.

The main set of individual level results on the effect of terrorism on life satisfaction are presented in Table 5. They are based on Ordered Logit regressions which include all the explanatory variables from Table 4 but add to them daily measures of terrorism intensity in order to estimate terrorism's "direct effect". In column 1 terrorism intensity is captured by the daily country-wide total number of

\footnotetext{
${ }^{10}$ City size refers to non-Arab population (source: Israel Central of Statistics, Statistical Abstract of Israel, 2003, Table $2.14)$.
} 
fatalities. The coefficient on this variable is negative but insignificant. In column 2 we examine whether the reaction of life satisfaction to terrorism is non-linear by including in the regression the number of fatalities and the number of fatalities squared. Both variables have an insignificant effect. In column 3 we further explore the issue of non-linearity by including in the regression the daily number of major terrorist attacks, where such attacks are defined as those that resulted in at least five fatalities. The coefficient of this variable is negative but insignificant. Overall, the evidence presented in columns 1 to 3 suggests that terrorism has had no same-day direct effect on the life satisfaction of Jewish residents of Israel.

In contrast, columns 4 to 6 of Table 5 provide evidence that terrorism has had a negative and statistically significant same-day direct effect on the life satisfaction of Arab-Israelis. Why do Arabs display a stronger negative reaction to terrorism than Jews, despite the fact that they are in general not the target of the attacks? Arab-Israelis have long seen themselves as a discriminated against minority. The outbreak of the Intifada in September 2000 was followed by severe clashes between the Israeli police and Arab-Israelis. Since then tensions between Jews and Arabs in the country have grown. ${ }^{11}$ It is thus possible that the effect we capture in Table 5 reflects the fear of Arab-Israelis that the intensification of terrorism may lead to increased discrimination against them. ${ }^{12}$

In Table 6 we explore the persistence of the life satisfaction reaction to terrorism by including in the regression the contemporaneous and three lags of the daily country-wide total number of fatalities. For Jews same-day fatalities still have no effect. The coefficient on the second lag is actually positive and significant. However, we believe that not too much should be made of this result as for all lag lengths the sum of the contemporaneous effect and the lags is insignificant. For Arabs, the contemporaneous effect is negative and significant. However, when examined with a two day, three day, or four day window the effect of terrorism on the life satisfaction of Arabs is insignificant. Overall, the results reported in Table 6 demonstrate that even when there is a same-day reaction to terrorism, this reaction does not last for more than a day.

One may argue that over time, as people gain experience dealing with terrorism, an attack of a given magnitude would yield a more muted reaction. We test this hypothesis by including in the analysis

\footnotetext{
${ }^{11}$ See Smooha (2004) for a recent analysis of Arab-Jewish relations in Israel.

${ }^{12}$ Our results are in line with findings in the psychological literature: based on a survey conducted in Israel in September 2003 Hobfoll et al. (2006) report that Arabs had significantly higher levels of PTSD than Jews; a similar finding is reported by Bleich et al. (2006). The hypothesis that terrorism may increase discrimination against certain minority groups has been explored (in the context of labor markets) by Aslund and Rooth (2005) for Sweden and Davila and Mora (2005) for the U.S.
} 
interactions between the daily number of fatalities and dummy variables for the years 2003 and 2004 (Table 7). The evidence does not seem to provide support for the habituation hypothesis, as all the interaction coefficients are insignificant.

In Table 8 we differentiate between security forces and civilian fatalities. For Jews the coefficient on security forces fatalities is negative while that on civilian fatalities is positive; both, however, are insignificant. When we further break down the civilian fatalities we find that the same-day reaction to civilian fatalities in one's own city is negative and marginally significant. The fact that individuals respond most strongly to fatalities in their own city makes intuitive sense and fits well with most of the findings in the psychological literature. Another interesting finding reported in Table 8 is that the negative life satisfaction reaction of Arabs to terrorism is restricted to civilian fatalities. ${ }^{13}$ This result may be related to our earlier discussion of discrimination and to the fact that most civilian fatalities were due to attacks in Jewish cities in Israel proper while most security forces fatalities were due to attacks in the Occupied Territories. Arab-Israelis, who regularly work and shop in Jewish cities in Israel, may expect to be treated with more suspicion and hostility following attacks (against civilian targets) in these cities than following attacks (against security forces targets) in the Occupied Territories.

\subsection{Why doesn't terrorism affect life satisfaction?}

In this section we first demonstrate that our analysis is robust to several potential criticisms and then discuss two alternative explanations for our "non-result": that Palestinian terrorism during the Intifada did not demoralize Israelis.

In the introduction we argued, based on the existing literature, that subjective measures of well-being (such as life satisfaction and happiness) are closely related to measures of mental health. The existence of such a relationship underlies our analysis. Here we provide additional, independent, evidence that the two concepts are indeed related. We do so by utilizing data from the Israeli Health Survey. The survey was initiated by the Israeli Ministry of Health as part of the International Mental Health Survey of the World Health Organization. The survey was conducted from May 2003 to May 2004 by the Central Bureau of Statistics and covered a representative sample of roughly 4,800 individuals aged 21 and older.

Two questions in the survey are most relevant for us. One asks "Overall, how would you rate your mental health?" The five possible answers were "definitely not good", "not so good", "good", "very

\footnotetext{
${ }^{13}$ For Arab-Israelis we do not further break down the civilian fatalities because practically none of the fatal terrorist attacks in the period under investigation took place in an Arab city.
} 
good", and "excellent". The second question asks "In the last 30 days, how often did you feel happy?" The four possible answers to this question were "never", "rarely", "every once in a while", and "often". Figure 3 strongly suggests that happiness is positively and strongly correlated with mental health. ${ }^{14}$ Figure 4 demonstrates that mental health, like life satisfaction, does not seem to be correlated with terrorism over time. ${ }^{15}$

Another potential concern we address has to do with the use of daily life satisfaction data. The number of Social Survey observations per day varies from 1 to 64, with an average of 23 and a median of 25. Is it possible that the lack of response of life satisfaction to terrorism (for Jews) at the daily frequency is due to noise associated with the small number of daily observations? In order to demonstrate that there is enough useful information in daily life satisfaction data we augment our regressions with daily weather data, obtained from the Israel Meteorological Service (IMS). ${ }^{16}$

We are interested in studying the effect of deviations of the weather from seasonal norms and therefore first adjust each weather series by regressing the original data on a full set of monthly dummies. Our analysis uses the residuals from these regressions. ${ }^{17}$ Table 9 shows the results of life satisfaction regressions which include the daily (residual) weather series, terrorism fatalities, and our baseline regressors. Weather patterns turn out to have an effect, although this effect is not tightly estimated: more sunshine and a higher minimum temperature raise life satisfaction; more precipitation, on the other hand, depresseses life satisfaction. ${ }^{18}$ Importantly, we find that terrorism continues to have an insignificant effect on life satisfaction. The results presented in Table 9 further strengthen our belief that the daily data on life satisfaction contain a sufficiently high signal to noise ratio to be useful for econometric analysis.

A third concern we address is whether our study misses an earlier break point in life satisfaction: one may argue that the outbreak of the Intifada (in September 2000) led to a sharp decline in happiness and

\footnotetext{
${ }^{14}$ The correlation between the two variables is 0.53 , which is statistically significant at the $1 \%$ level. The Health Survey also contains data on mental health symptoms such as stress, depression, and sleeplessness. All are significantly correlated with happiness.

${ }^{15}$ The analysis excludes May 2003 and May 2004, the two months with lowest number of observations (for May 2003 we have 47 observations, or $1 \%$ of the total; for May 2004 we have 25 observations, or $0.5 \%$ of the total). Note that the data we obtained identifies only the month but not the date in which each survey was conducted.

${ }^{16}$ The meteorological measurements were taken at the headquarters of the IMS in Bet-Dagan, a suburb of Tel-Aviv. Rehdanz and Maddison (2005) study the effect of climate on happiness in a cross-country context using annual data.

${ }^{17}$ See Hirshleifer and Shumway (2003) for an application of a similar approach.

${ }^{18}$ In additional analysis (not reported) we find that, controlling for the weather variables, life satisfaction is lowest in the fall (September-November). This is likely a reflection of the well-known seasonal affective disorder (SAD). See Kamstra et al. (2003) for discussion of SAD.
} 
that afterwards additional acts of terrorism had negligible effects. We are unable to address this issue directly since the Social Survey data is only available from 2002. Instead, we use data on life satisfaction from public opinion polls, as reported by Elran (2006). The polls were conducted (on irregular basis) starting in 1995 by Dahaf, a leading polling company in Israel, with each poll covering around 500 respondents. ${ }^{19}$ One of the questions in the polls asked individuals to rate their current satisfaction with life on a scale of 1 to 9 . Figure 5 demonstrates that the start of the Intifada was accompanied by a sharp drop in life satisfaction and that this drop was reversed by late $2003 .^{20}$ However, it is not clear to what extent these public opinion polls data contradict our conclusion that the direct effect of terrorism is minimal. First, the figure displays a sharp rise in life satisfaction from February 2002 to November 2003, which is not mirrored in the more comprehensive Social Survey data that we use (see Figure 1A). Second, it is quite likely that the results displayed in Figure 5 were influenced by the severe economic slump that Israel suffered from during the early part of the Intifada (see Figure 6). In other words, unlike our analysis, the figure does not separate between the direct and the indirect effects of terrorism.

Assuming that our results are robust to the concerns raised above, how could we account for the study's main finding: that terrorism has had a negligible effect on the happiness of Israelis? We discuss two possible explanations. The first has to do with government action to curb terrorism. We argue that public morale may depend on the perceived stance and competence of the government in combating terrorism. If the government is perceived to be passive or if its counter-terrorism measures are perceived as ineffective, the public may become demoralized. If, on the other hand, the perception is that the government is active and its policies effective then public morale may be less affected by terrorism. During the Intifada, and especially since the spring of 2002, Israel's counter-terrorism strategy proved successful in curbing Palestinian terrorism (see Table 1 and Figure 1A). This may help to explain why the Israeli public did not become demoralized.

We explore this hypothesis econometrically by estimating the effect on life satisfaction of Israeli assassination attempts against members of Palestinian terrorist organizations. During the Intifada assassinations were a key element in Israel's counter-terrorism strategy. The data we use is drawn from Zussman and Zussman (2006) who study stock market reactions to assassinations. The dataset, which covers the period from January 2002 to April 2004, contains the day and the time of each assassination

\footnotetext{
${ }^{19}$ The statistical error associated with these public opinion polls is $+/-4.5$ percentage points.

${ }^{20}$ Regressing (by OLS) the level of life satisfaction on an Intifada dummy that takes the value of 1 from April 2001 to November 2004 yields an insignificant negative coefficient. However, if the Intifada dummy takes the value of 1 only in April 2001 (or in April 2001 and February 2002) the regression yields a negative and highly significant coefficient.
} 
attempt and differentiates between successful and failed attempts. ${ }^{21}$ Table 10 demonstrates that assassination attempts, and especially successful ones, have a large positive effect on life satisfaction. This lends support to our hypothesis that counter-terrorism actions by the government may have contributed to raising the morale of Israelis during the Intifada.

A second possible explanation for the paper's main finding has to do with the concept of resilience. This concept is used in psychology to describe the capacity of people to cope with difficult circumstances without manifesting symptoms of psychological dysfunction. Resilience is acquired through the development of coping strategies, which enable the individual to remove the stressor or to ameliorate its effects. Regardless of which coping strategies Israelis were employing during the Intifada ${ }^{22}$, our results strongly suggest that resiliency enabled them to attenuate the detrimental psychological effects of prolonged and repeated exposure to terrorism.

\section{Conclusion}

This paper studied the effect of Palestinian terrorism on the morale of Israelis during the recent Intifada by using detailed daily data on terrorism and life satisfaction. Its main conclusion is that Palestinian terrorism has had practically no effect on the happiness of Israelis. Our econometric analysis showed that the number of country-wide terrorism fatalities had no direct same-day effect on the life satisfaction of Jewish Israelis. On the other hand, Arab citizens of Israel displayed a negative same-day reaction to terrorism fatalities, although this reaction did not persist for more than a day. We argued that the initial negative reaction of Arabs may be related to increasing concerns of discrimination against them. Using an independent data source we demonstrated that mental health, like life satisfaction, was not influenced by terrorism.

Our analysis makes a methodological contribution to the study of happiness. We demonstrated that one can fruitfully use detailed high-frequency data on life satisfaction to study the effects of recurring unpredicted exogenous events. The substantive contribution of the analysis lies in the examination of a previously under-studied but very important question of the effect of terrorism on life satisfaction. The evidence we presented casts a doubt on the effectiveness of terrorism in achieving one of its objectives - demoralizing the enemy population.

\footnotetext{
${ }^{21}$ Overall there are 92 assassination attempts in the dataset, 81 of which were successful.

${ }^{22}$ See Elran (2006) for a discussion of this issue.
} 


\section{References}

[1] Aslund, Olof and Rooth, Dan-Olof. "Shifts in Attitudes and Labor Market Discrimination: Swedish Experiences after 9-11.” Journal of Population Economics, November 2005, 18(4), pp. 603-629.

[2] Blanchflower, David G. and Oswald, Andrew J. "Hypertension and Happiness across Nations." Institute for the Study of Labor (IZA) Discussion Paper No. 2633, February 2007.

[3] Bleich, Avraham; Gelkopf, Marc; Melamed, Yuval; and Solomon, Zahava. "Mental Health and Resiliency Following 44 Months of Terrorism: A Survey of an Israeli National Representative Sample." BMC Medicine, August 2006, 4(21), pp. 1-43.

[4] Bleich, Avraham; Gelkopf, Marc and Solomon, Zahava. "Exposure to Terrorism, StressRelated Mental Health Symptoms, and Coping Behaviors Among a Nationally Representative Sample in Israel." Journal of the American Medical Association, August 2003, 290(5), pp. 612-620.

[5] Cohen Silver, Roxane; Holman, E. Alison; McIntosh, Daniel N.; Poulin, Michael and Gil-Rivas, Virginia. "Nationwide Longitudinal Study of Psychological Responses to September 11." Journal of the American Medical Association, September 2002, 288(10), pp. 1235-1244.

[6] Davila, Alberto and Mora, Marie T. "Changes in the Earnings of Arab Men in the US between 2000 and 2002." Journal of Population Economics, November 2005, 18(4), pp. 587-601.

[7] Di Tella, Rafael and MacCulloch, Robert. "Some Uses of Happiness Data in Economics." Journal of Economic Perspectives, Winter 2006, 20(1), pp. 25-46.

[8] Eckstein, Zvi and Tsiddon, Daniel. "Macroeconomic Consequences of Terror: Theory and the Case of Israel." Journal of Monetary Economics, July 2004, 51(5), pp. 971-1002.

[9] Elran, Meir. "Israel's National Resilience: The Influence of the Second Intifada on Israeli Society." Tel Aviv University Jaffee Center for Strategic Studies, Working Paper No. 81, January 2006. [in Hebrew]

[10] Frey, Bruno S.; Luechinger, Simon and Stutzer, Alois. "Valuing Public Goods: The Life Satisfaction Approach.” Zurich University Institute for Empirical Research in Economics Working Paper No. 184, March 2004. 
[11] Frey, Bruno S.; Luechinger, Simon and Stutzer, Alois. "Calculating Tragedy: Assessing the Costs of Terrorism." Journal of Economic Surveys, February 2007, 21(1), pp. 1-24.

[12] Frey, Bruno S. and Stutzer, Alois. "Happiness Research: State and Prospects." Review of Social Economy, June 2005, 62(2), pp. 207-228.

[13] Friedland, Nehemia and Merari, Ariel. "The Psychological Impact of Terrorism: A DoubleEdged Sword." Political Psychology, December 1985, 6(4), pp. 591-604.

[14] Galea, Sandro; Ahern, Jennifer; Resnick, Heidi; Kilpatrick, Dean; Bucuvalas, Michael; Gold, Joel; Vlahvov, David. "Psychological Sequelae of the September 11 Terrorist Attacks in New York City." New England Journal of Medicine, March 2002, 346(13), pp. 982-987.

[15] Hirshleifer, David and Shumway, Tyler. "Good Day Sunshine: Stock Returns and the Weather." Journal of Finance, June 2003, 58(3), pp. 1009-1032.

[16] Hobfoll, Stevan E.; Canetti-Nisim, Daphna and Johnson, Robert J. "Exposure to Terrorism, Stress-Related Mental Health Symptoms, and Defensive Coping Among Jews and Arabs in Israel." Journal of Consulting and Clinical Psychology, April 2006, 74(2), pp. 207-218.

[17] Hoffman, Bruce. Inside Terrorism, rev. ed., New York: Columbia University Press, 2006.

[18] Kahneman, Daniel and Krueger, Alan B. "Developments in the Measurement of Subjective Well-Being." Journal of Economic Perspectives, Winter 2006, 20(1), pp. 3-24.

[19] Kamstra, Mark J.; Kramer, Lisa A. and Levi, Maurice D. "Winter Blues: A SAD Stock Market Cycle." Amerian Economic Review, March 2003, 93(1), pp. 324-343.

[20] Kimball, Miles; Levy, Helen; Ohtake, Fumio and Tsutsui, Yoshiro. "Unhappiness after Hurricane Katrina.” NBER Working Paper No. 12062, February 2006.

[21] Layard, Richard. Happiness: Lessons from a New Science. London: Penguin, 2005.

[22] Rehdanz, Katrin and Maddison, David. "Climate and Happiness." Ecological Economics, January 2005, 52(1), pp. 111-125.

[23] Schlenger, William E.; Caddell, Juesta M.; Ebert, Lori; Jordan, B. Kathleen; Rourke, Kathryn M.; Wilson, David; Thalji, Lisa; Dennis, J. Michael; Fairbank, John A.; Kulka, Richard A. "Psychological Reactions to Terrorist Attacks: Findings From the National 
Study of Americans' Reactions to September 11." Journal of the American Medical Association, August 2002, 288(5), pp. 581-588.

[24] Schuster, Mark A.; Stein, Bradley D.; Jaycox, Lisa H.; Collins, Rebecca L.; Marshall, Grant N.; Elliott, Marc N.; Zhou, Annie J.; Kanouse, David E.; Morrison, Janina L.; Berry, Sandra H. "A National Survey of Stress Reactions after the September 11, 2001 Terrorist Attacks." New England Journal of Medicine, November 2001, 345(20), pp. 1507-1512.

[25] Shalev, Arieh Y.; Tuval, Rivka; Frenkiel-Fishman, Sarah; Hadar, Hilit and Eth, Spencer. "Psychological Responses to Continuous Terror: A Study of Two Communities in Israel." American Journal of Psychiatry, April 2006, 163(4), pp. 667-673.

[26] Smooha, Sammy. "Arab-Jewish Relations in Israel: A Deeply Divided Society." in Anita Shapira, ed., Israeli Identity in Transition, Westport, CT: Praeger, 2004, pp. 31-67.

[27] Zussman, Asaf and Zussman, Noam. "Assassinations: Evaluating the Effectiveness of an Israeli Counterterrorism Policy Using Stock Market Data." Journal of Economic Perspectives, Spring 2006, 20(2), pp. 193-206. 
TABLE 1: TERRORISM FATALITIES IN ISRAEL 2002-2004

\begin{tabular}{lccc}
\hline & 2002 & 2003 & 2004 \\
\hline Civilians & 297 & 156 & 74 \\
Security Forces & 159 & 57 & 42 \\
\hline Total & 456 & 213 & 116 \\
\hline $\begin{array}{l}\text { Source: } \text { Based on a dataset compiled by the authors as } \\
\text { described in the text. }\end{array}$
\end{tabular}


TABLE 2: LIFE SATISFACTION IN ISRAEL

2002-2004

(distribution of responses in percent)

\begin{tabular}{lccc}
\hline & 2002 & 2003 & 2004 \\
\hline Very satisfied & 26.6 & 27.2 & 28.0 \\
Fairly satisfied & 56.3 & 54.5 & 54.4 \\
Not very satisfied & 13.8 & 14.2 & 13.6 \\
Not at all satisfied & 3.3 & 4.1 & 4.0 \\
\hline Observations & 6,938 & 7,189 & 7,581 \\
\hline Source: Authors' calculations based on Israeli \\
Social Surveys.
\end{tabular}


Table 3: Life Satisfaction in Comparative Perspective ISRAEL VERSUS THE EU-15 COUNTRIES

\begin{tabular}{rlcccccc}
\hline & & \multicolumn{3}{c}{ Level (\%) } & \multicolumn{3}{c}{ Rank } \\
\cline { 2 - 7 } & 2002 & 2003 & 2004 & 2002 & 2003 & 2004 \\
\hline 1 & Denmark & 97 & 96 & 97 & 1 & 1 & 1 \\
2 & Sweden & 92 & 93 & 96 & 3 & 2 & 2 \\
3 & Luxembourg & 95 & 87 & 95 & 2 & 6 & 3 \\
4 & Finland & 91 & 91 & 94 & 5 & 4 & 4 \\
5 & The Netherlands & 92 & 91 & 92 & 4 & 3 & 6 \\
6 & Ireland & 87 & 85 & 93 & 6 & 7 & 5 \\
7 & United Kingdom & 86 & 88 & 90 & 7 & 5 & 8 \\
8 & Belgium & 81 & 83 & 91 & 10 & 8 & 7 \\
9 & Austria & 83 & 82 & 85 & 8 & 10 & 10 \\
10 & Spain & 80 & 83 & 86 & 11 & 9 & 9 \\
11 & France & 78 & 76 & 82 & 13 & 13 & 12 \\
12 & Italy & 80 & 76 & 76 & 12 & 12 & 14 \\
13 & Germany & 78 & 73 & 84 & 14 & 14 & 11 \\
14 & Greece & 58 & 63 & 66 & 16 & 15 & 15 \\
15 & Portugal & 59 & 56 & 59 & 15 & 16 & 16 \\
\hline & EU-15 & $\mathbf{8 2}$ & $\mathbf{8 1}$ & $\mathbf{8 5}$ & & & \\
\hline & Israel & $\mathbf{8 3}$ & $\mathbf{8 2}$ & $\mathbf{8 2}$ & $\mathbf{9}$ & $\mathbf{1 1}$ & $\mathbf{1 3}$ \\
\hline
\end{tabular}

Notes: Columns 1-3 show for each country and year the share (in \%) of those indicating that they are "very satisfied" or "fairly satisfied" with the life they lead; columns 4-6 show the corresponding rankings; the EU-15 countries are listed in descending order of their average rank across the three years.

Source: Authors' calculations based on Eurobarometer surveys (58, 60, and 62) and Israeli Social Surveys. 
TABLE 4: BASELINE LIFE SATISFACTION EQUATIONS

\begin{tabular}{|c|c|c|c|c|}
\hline & \multicolumn{2}{|c|}{ Ordered Logit } & \multicolumn{2}{|c|}{ Logit } \\
\hline & Jews & Arabs & Jews & Arabs \\
\hline & 1 & 2 & 3 & 4 \\
\hline Male & $\begin{array}{c}0.068^{* *} \\
(0.031)\end{array}$ & $\begin{array}{c}-0.284^{* * *} \\
(0.083)\end{array}$ & $\begin{array}{l}0.076^{*} \\
(0.044)\end{array}$ & $\begin{array}{c}-0.342^{* * *} \\
(0.106)\end{array}$ \\
\hline Age & $\begin{array}{c}-0.113^{* * *} \\
(0.006)\end{array}$ & $\begin{array}{c}-0.059^{* * *} \\
(0.017)\end{array}$ & $\begin{array}{c}-0.109^{* * *} \\
(0.008)\end{array}$ & $\begin{array}{c}-0.069^{* * *} \\
(0.025)\end{array}$ \\
\hline Age squared & $\begin{array}{c}0.001^{* * *} \\
(0.000)\end{array}$ & $\begin{array}{c}0.001^{* * *} \\
(0.000)\end{array}$ & $\begin{array}{c}0.001^{* * *} \\
(0.000)\end{array}$ & $\begin{array}{c}0.001^{* * *} \\
(0.000)\end{array}$ \\
\hline Married & $\begin{array}{c}0.706^{* * *} \\
(0.039)\end{array}$ & $\begin{array}{c}0.554^{* * * *} \\
(0.105)\end{array}$ & $\begin{array}{c}0.832^{* * *} \\
(0.053)\end{array}$ & $\begin{array}{c}0.516^{* * *} \\
(0.139)\end{array}$ \\
\hline Number of children & $\begin{array}{c}0.074^{* * *} \\
(0.014)\end{array}$ & $\begin{array}{l}-0.022 \\
(0.025)\end{array}$ & $\begin{array}{l}0.082^{* * *} \\
(0.021)\end{array}$ & $\begin{array}{c}0.010^{* * *} \\
(0.034)\end{array}$ \\
\hline Post-secondary education & $\begin{array}{l}0.075^{*} \\
(0.042)\end{array}$ & $\begin{array}{l}-0.055 \\
(0.145)\end{array}$ & $\begin{array}{c}0.166^{* * *} \\
(0.060)\end{array}$ & $\begin{array}{c}0.100^{* * *} \\
(0.209)\end{array}$ \\
\hline Academic education & $\begin{array}{c}0.156^{* * *} \\
(0.039)\end{array}$ & $\begin{array}{l}0.152 \\
(0.139)\end{array}$ & $\begin{array}{c}0.419^{* * *} \\
(0.061)\end{array}$ & $\begin{array}{c}0.748^{* * *} \\
(0.273)\end{array}$ \\
\hline Poor health & $\begin{array}{c}-0.663^{* * *} \\
(0.036)\end{array}$ & $\begin{array}{c}-1.030^{* * *} \\
(0.105)\end{array}$ & $\begin{array}{c}-0.812^{* * *} \\
(0.047)\end{array}$ & $\begin{array}{c}-1.074^{* * *} \\
(0.119)\end{array}$ \\
\hline Religious & $\begin{array}{c}0.226^{* * * *} \\
(0.040)\end{array}$ & $\begin{array}{l}-0.033 \\
(0.090)\end{array}$ & $\begin{array}{c}0.276^{* * * *} \\
(0.057)\end{array}$ & $\begin{array}{c}0.203^{* * *} \\
(0.113)\end{array}$ \\
\hline Very religious & $\begin{array}{c}1.247^{* * *} \\
(0.073)\end{array}$ & $\begin{array}{c}0.471^{* * *} \\
(0.146)\end{array}$ & $\begin{array}{c}1.489^{* * *} \\
(0.174)\end{array}$ & $\begin{array}{c}0.545^{* * *} \\
(0.186)\end{array}$ \\
\hline Immigrant & $\begin{array}{c}-0.783^{* * *} \\
(0.040)\end{array}$ & & $\begin{array}{c}-0.663^{* * *} \\
(0.053)\end{array}$ & \\
\hline Per-capita family income & $\begin{array}{c}0.083^{* * *} \\
(0.006)\end{array}$ & $\begin{array}{c}0.157^{* * *} \\
(0.036)\end{array}$ & $\begin{array}{c}0.133^{* * * *} \\
(0.015)\end{array}$ & $\begin{array}{c}0.352^{* * *} \\
(0.095)\end{array}$ \\
\hline Unemployed & $\begin{array}{c}-0.597^{* * *} \\
(0.068) \\
\end{array}$ & $\begin{array}{c}-0.583^{* * *} \\
(0.146) \\
\end{array}$ & $\begin{array}{c}-0.621^{* * *} \\
(0.079) \\
\end{array}$ & $\begin{array}{c}-0.433^{* * *} \\
(0.175) \\
\end{array}$ \\
\hline Observations & 18,007 & 2,724 & 18,007 & 2,724 \\
\hline
\end{tabular}

Notes: Dependent variable - reported life satisfaction; standard errors in parentheses; ; ${ }^{* *},{ }^{* * *}$ represent statistical significance at the 10,5 , and 1 percent levels; regressions 1 and 2 estimated by Ordered Logit; regressions 3 and 4 estimated by Logit and include an intercept (not reported); immigrants are defined as foreign born individuals who moved to Israel since 1989 (this variable was excluded from columns 2 and 4 since there are no Arab immigrants).

Source: Authors' calculations based on Israeli Social Surveys. 
TABLE 5: EFFECT OF TERRORISM ON LIFE SATISFACTION

\begin{tabular}{lcccccc}
\hline & \multicolumn{3}{c}{ Jews } & \multicolumn{3}{c}{ Arabs } \\
\cline { 2 - 7 } & 1 & 2 & 3 & 4 & 5 & 6 \\
\hline Fatalities & -0.003 & -0.011 & & $-0.034^{* *}$ & $-0.100^{*}$ & \\
& $(0.007)$ & $(0.019)$ & & $(0.017)$ & $(0.060)$ & \\
Fatalities squared & & 0.001 & & & 0.005 & \\
& & $(0.001)$ & & & $(0.004)$ & \\
Major attacks & & -0.015 & & & $-0.499^{* *}$ \\
& & & $(0.089)$ & & & $(0.227)$ \\
\hline Baseline regressors & Yes & Yes & Yes & Yes & Yes & Yes \\
\hline Observations & 18,007 & 18,007 & 18,007 & 2,724 & 2,724 & 2,724 \\
\hline Notes: Dependent variable - reported life satisfaction; standard errors in parentheses; ${ }^{* * *},{ }^{* * *}$ & \\
represent statistical significance at the 10, 5, and 1 percent levels; estimated by Ordered \\
Logit; baseline regressors are from Table 4. & & & \\
Source: Authors' calculations based on Israeli Social Surveys. & & &
\end{tabular}


TABle 6: How Persistent IS The EfFect OF TerrorisM?

\begin{tabular}{|c|c|c|c|c|}
\hline & \multicolumn{2}{|c|}{ Jews } & \multicolumn{2}{|c|}{ Arabs } \\
\hline & 1 & 2 & 3 & 4 \\
\hline Fatalities - same day & $\begin{array}{l}-0.003 \\
(0.007)\end{array}$ & $\begin{array}{l}-0.002 \\
(0.007)\end{array}$ & $\begin{array}{c}-0.034^{* *} \\
(0.017)\end{array}$ & $\begin{array}{c}-0.035^{* *} \\
(0.017)\end{array}$ \\
\hline Fatalities - lag 1 day & & $\begin{array}{l}0.009 \\
(0.007)\end{array}$ & & $\begin{array}{c}0.002 \\
(0.017)\end{array}$ \\
\hline Fatalities - lag 2 days & & $\begin{array}{c}0.016^{* *} \\
(0.007)\end{array}$ & & $\begin{array}{l}0.010 \\
(0.018)\end{array}$ \\
\hline Fatalities - lag 3 days & & $\begin{array}{l}-0.007 \\
(0.008) \\
\end{array}$ & & $\begin{array}{l}0.032^{*} \\
(0.018)\end{array}$ \\
\hline Baseline regressors & Yes & Yes & Yes & Yes \\
\hline Observations & 18,007 & 18,007 & 2,724 & 2,724 \\
\hline
\end{tabular}


TABLE 7: Is THERE HABITUATION TO TERRORISM?

\begin{tabular}{lcccc}
\hline & \multicolumn{2}{c}{ Jews } & \multicolumn{2}{c}{ Arabs } \\
\cline { 2 - 5 } & 1 & 2 & 3 & 4 \\
\hline Fatalities & -0.003 & -0.001 & $-0.034^{* *}$ & -0.026 \\
& $(0.007)$ & $(0.009)$ & $(0.017)$ & $(0.026)$ \\
Fatalities*2003 dummy & & -0.008 & & -0.004 \\
& & $(0.016)$ & & $(0.037)$ \\
Fatalities*2004 dummy & & 0.002 & & -0.029 \\
& & $(0.020)$ & & $(0.046)$ \\
\hline Baseline regressors & Yes & Yes & Yes & Yes \\
\hline Observations & 18,007 & 18,007 & 2,724 & 2,724 \\
\hline Notes: Dependent variable - reported life satisfaction; standard errors in \\
parentheses; ${ }^{* * *},{ }^{* * *}$ represent statistical significance at the 10, 5, and 1 \\
percent levels; estimated by Ordered Logit; baseline regressors are from \\
Table 4. \\
Source: Authors' calculations based on Israeli Social Surveys.
\end{tabular}


TABLE 8: INFLUENCE OF VICTIM CHARACTERISTICS

\begin{tabular}{|c|c|c|c|c|c|}
\hline & \multicolumn{3}{|c|}{ Jews } & \multicolumn{2}{|c|}{ Arabs } \\
\hline & 1 & 2 & 3 & 4 & 5 \\
\hline Fatalities & $\begin{array}{l}-0.003 \\
(0.007)\end{array}$ & & & $\begin{array}{c}-0.034^{* *} \\
(0.017)\end{array}$ & \\
\hline Security forces fatalities & & $\begin{array}{l}-0.010 \\
(0.014)\end{array}$ & $\begin{array}{l}-0.011 \\
(0.014)\end{array}$ & & $\begin{array}{c}-0.006 \\
(0.054)\end{array}$ \\
\hline Civilian fatalities & & $\begin{array}{l}0.001 \\
(0.009)\end{array}$ & & & $\begin{array}{c}-0.039^{* *} \\
(0.019)\end{array}$ \\
\hline in own city in Israel & & & $\begin{array}{c}-0.061^{*} \\
(0.034)\end{array}$ & & \\
\hline in other cities in Israel & & & $\begin{array}{c}0.005 \\
(0.029)\end{array}$ & & \\
\hline in Occupied Territories & & & $\begin{array}{l}0.005 \\
(0.010) \\
\end{array}$ & & \\
\hline Baseline regressors & Yes & Yes & Yes & Yes & Yes \\
\hline Observations & 18,007 & 18,007 & 18,007 & 2,724 & 2,724 \\
\hline
\end{tabular}


TABLE 9: EFFECT OF WEATHER ON LIFE SATISFACTION

\begin{tabular}{|c|c|c|c|c|c|}
\hline & 1 & 2 & 3 & 4 & 5 \\
\hline Sunshine & $\begin{array}{l}0.013^{*} \\
(0.007)\end{array}$ & & & & $\begin{array}{l}0.013^{*} \\
(0.008)\end{array}$ \\
\hline Maximum temperature & & $\begin{array}{c}0.005 \\
(0.005)\end{array}$ & & & $\begin{array}{l}-0.002 \\
(0.006)\end{array}$ \\
\hline Minimum temperature & & & $\begin{array}{l}0.010 \\
(0.006)\end{array}$ & & $\begin{array}{c}0.015^{* *} \\
(0.007)\end{array}$ \\
\hline Precipitation & & & & $\begin{array}{c}-0.006^{* *} \\
(0.003)\end{array}$ & $\begin{array}{l}-0.004 \\
(0.003)\end{array}$ \\
\hline Terrorism fatalities & $\begin{array}{l}-0.005 \\
(0.007) \\
\end{array}$ & $\begin{array}{r}-0.002 \\
(0.007) \\
\end{array}$ & $\begin{array}{r}-0.002 \\
(0.007) \\
\end{array}$ & $\begin{array}{c}-0.003 \\
(0.007) \\
\end{array}$ & $\begin{array}{l}-0.005 \\
(0.007) \\
\end{array}$ \\
\hline Baseline regressors & Yes & Yes & Yes & Yes & Yes \\
\hline Observations & 17,605 & 17,987 & 17,987 & 17,987 & 17,605 \\
\hline
\end{tabular}

Notes: Dependent variable - reported life satisfaction; the weather variables are residuals from OLS regressions of the original series on a set of month dummies; units: sunshine in hours, minimum and maximum temperature in degrees centigrade, precipitation in millimeters; weather measurements were taken in Bet-Dagan (headquarters of the Israel Meteorological Service); regressions estimated for Jewish respondents only; standard errors in parentheses; ${ }^{*},{ }^{* *},{ }^{* * *}$ represent statistical significance at the 10,5 , and 1 percent levels; estimated by Ordered Logit; baseline regressors are from Table 4.

Source: Authors' calculations based on Israeli Social Surveys and data provided by the Israel Meteorological Service. 
TABLE 10: EfFEct OF Assassination ATTEMPTS ON LIFE SATISFACTION

\begin{tabular}{lcc}
\hline & All Attempts & Successful Attempts \\
\hline Assassination attempt & 0.083 & $0.095^{*}$ \\
& $(0.052)$ & $(0.055)$ \\
Terrorism fatalities & -0.003 & -0.003 \\
& $(0.007)$ & $(0.007)$ \\
\hline Baseline regressors & Yes & Yes \\
\hline Observations & 18,007 & 18,007 \\
\hline Notes: Dependent variable - reported life satisfaction; see Zussman and \\
Zussman (2006) for description of the assassinations dataset; the period \\
covered is January 2002 - April 2004; regressions estimated for Jewish \\
respondents only; standard errors in parentheses; ${ }^{* *}{ }^{* * *}$, represent \\
statistical significance at the 10, 5, and 1 percent levels; estimated by \\
Ordered Logit; baseline regressors are from Table 4. \\
Source: Authors' calculations based on Israeli Social Surveys and \\
Zussman and Zussman (2006).
\end{tabular}


FIGURE 1A: TERRORISM FATALITIES AND LIFE SATISFACTION IN ISRAEL

January 2002 - December 2004

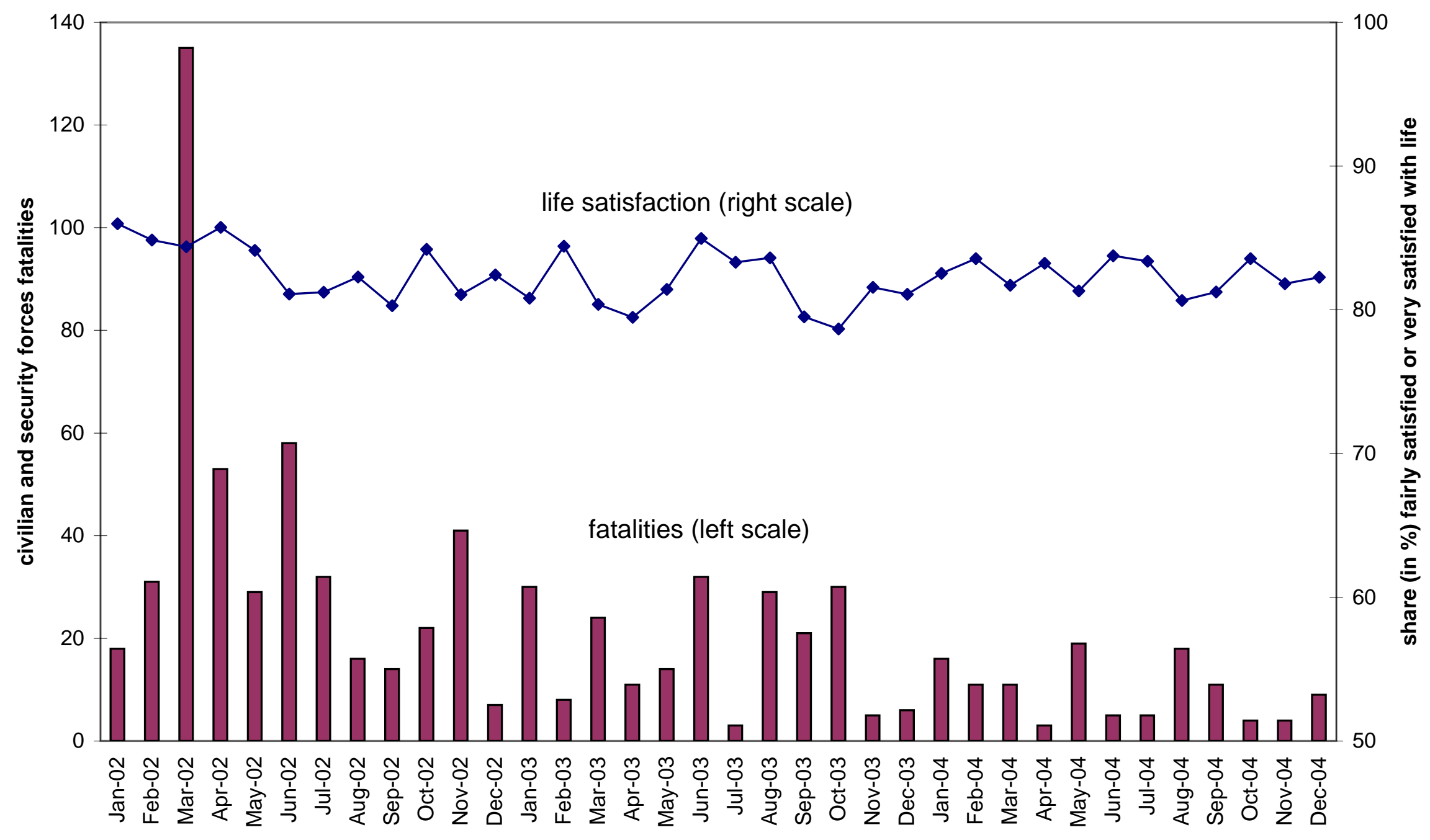


FIGURE 1B - TERRORISM FATALITIES AND LIFE SATISFACTION IN ISRAEL

January 2002 - December 2004

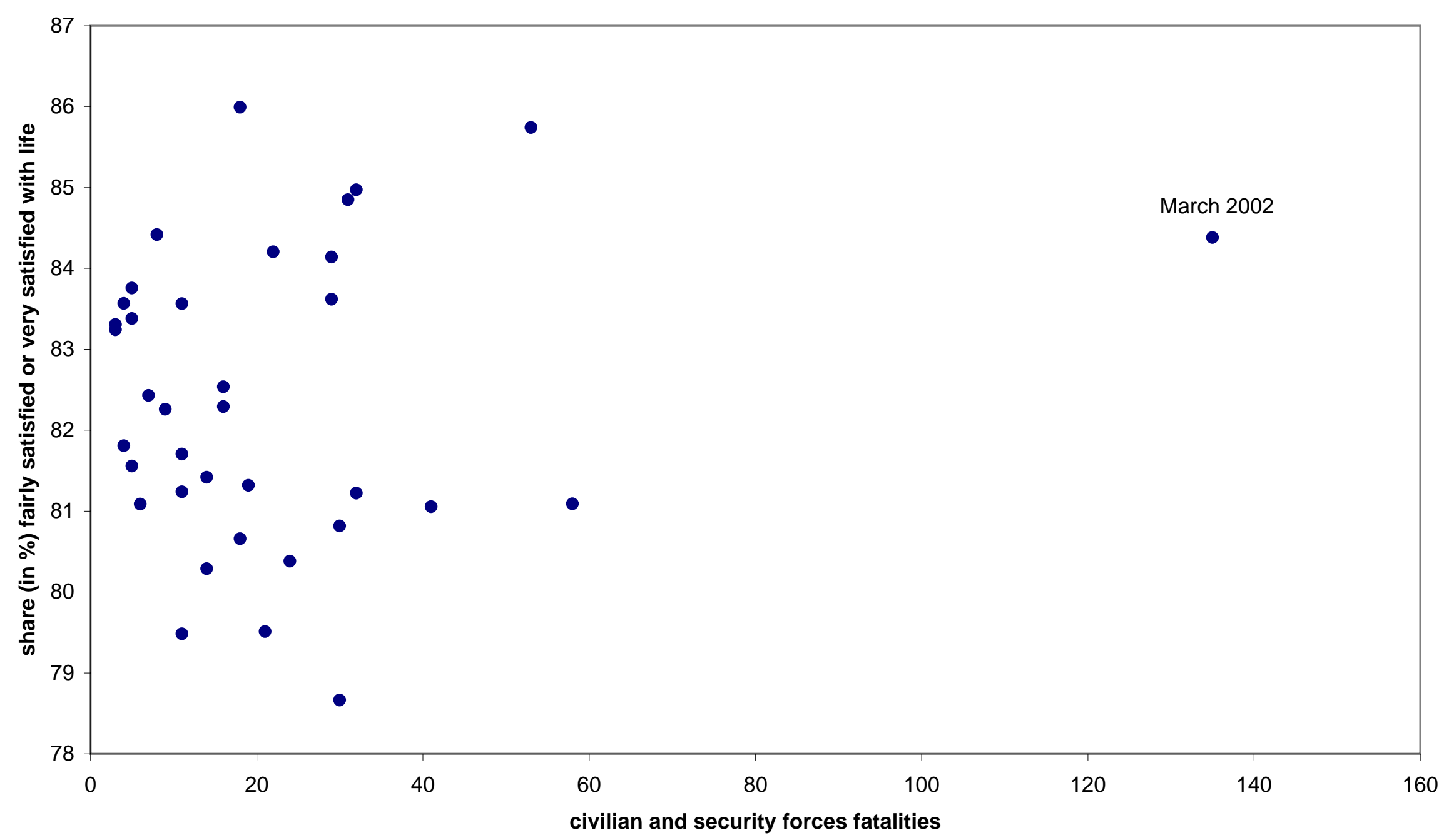


FIGURE 2: TERRORISM INTENSITY AND LIFE SATISFACTION IN CITIES

Israel's eight major cities, 2002-2004

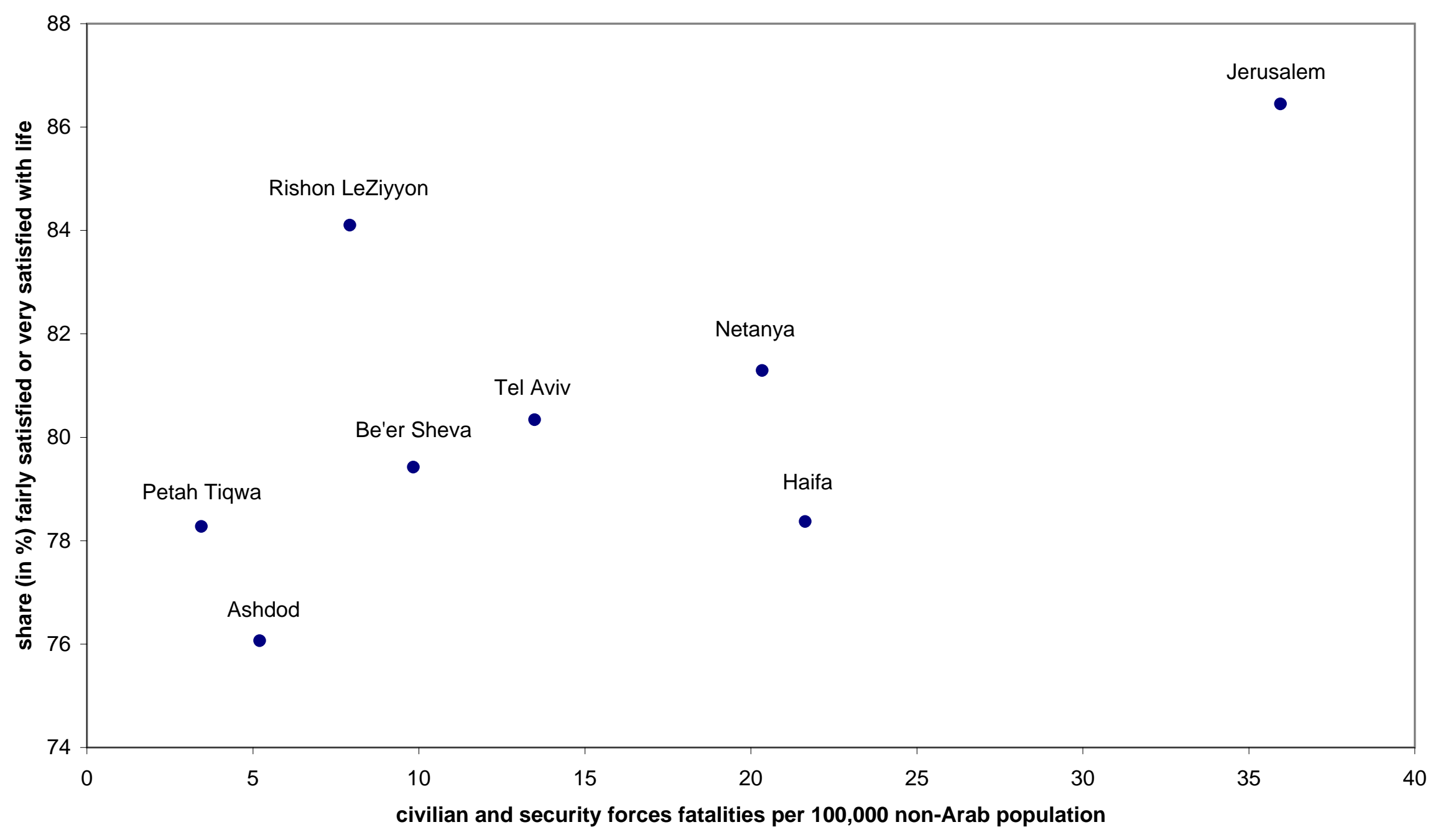


FIGURE 3: HAPPINESS AND MENTAL HEALTH IN ISRAEL

Israel Health Survey, May 2003 - May 2004

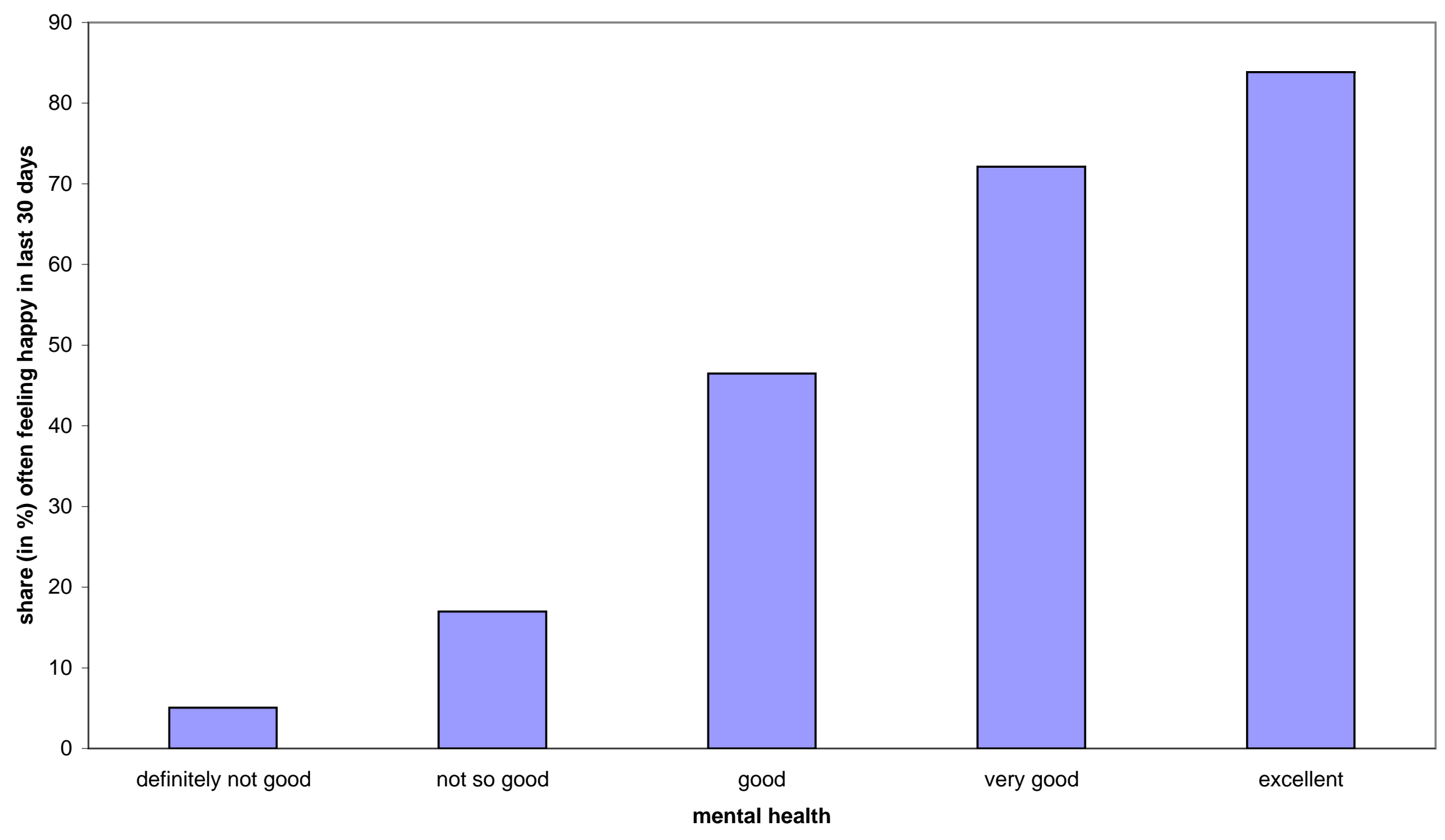


FIGURE 4: TERRORISM FATALITIES AND MENTAL HEALTH IN ISRAEL

June 2003 - April 2004

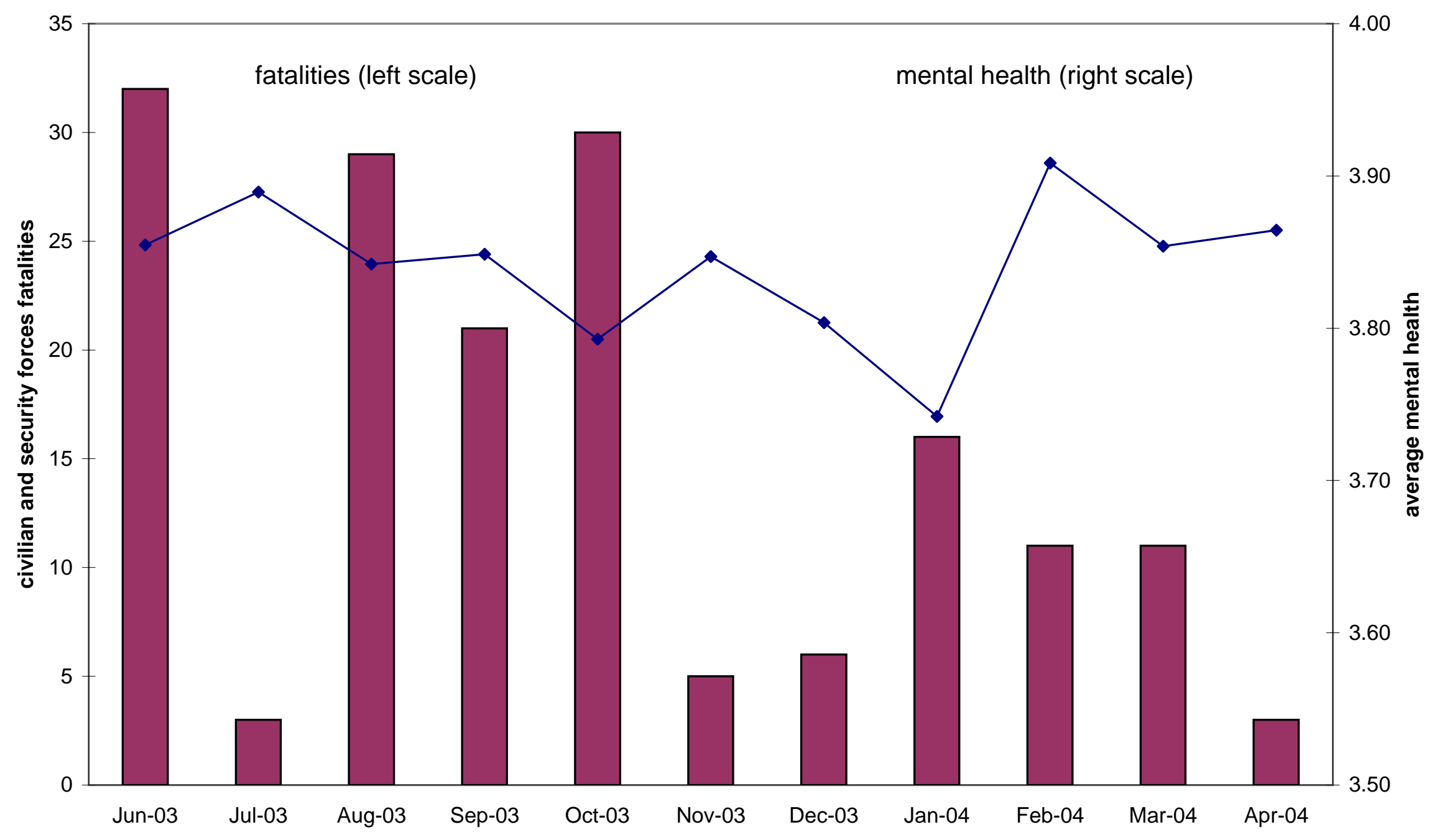


FIGURE 5: LONG-RUN PERSPECTIVE ON LIFE SATISFACTION IN ISRAEL public opinion polls, January 1995 - November 2004

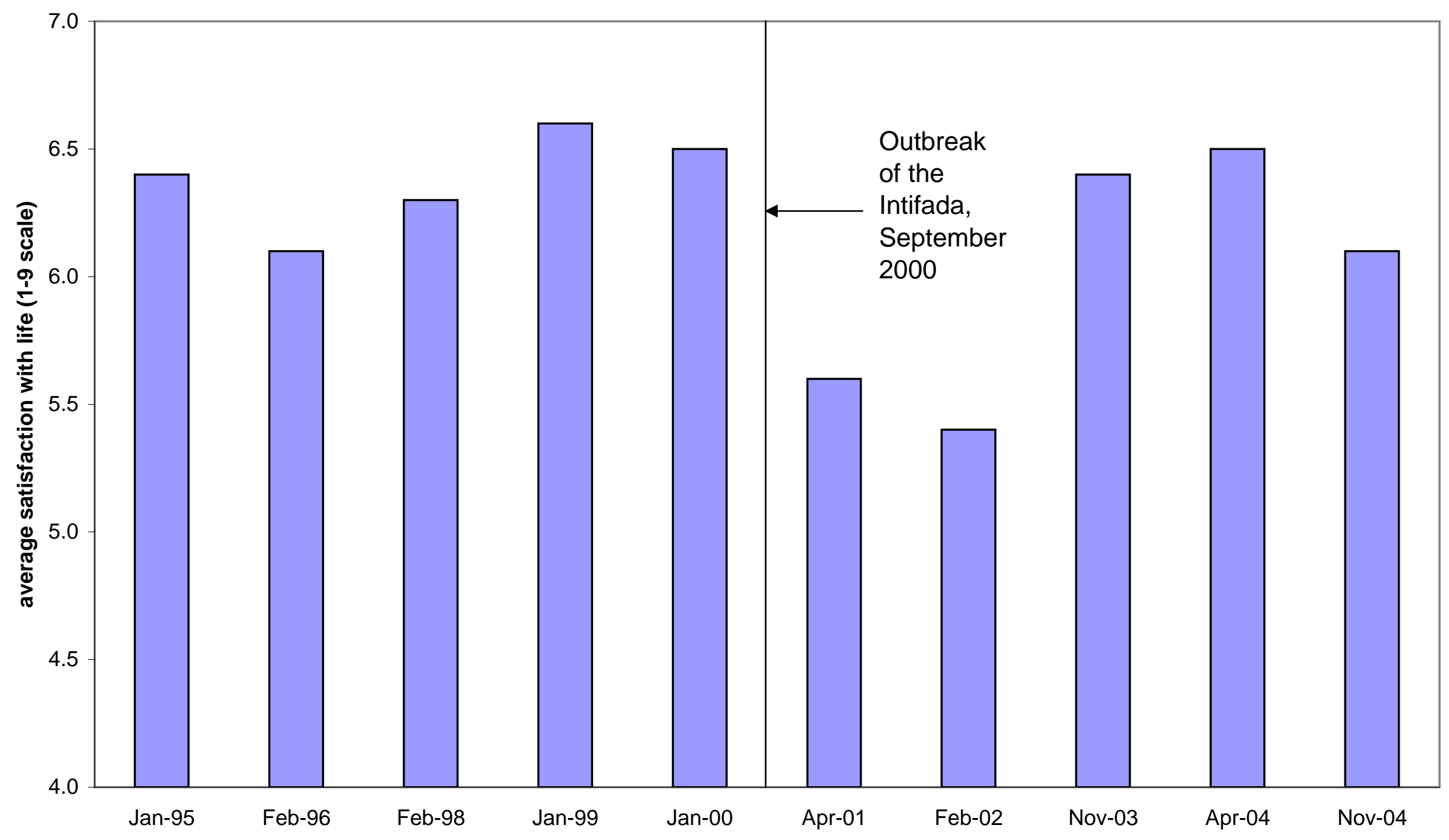


FIGURE 6: GROWH RATE OF REAL PER CAPITA GDP IN ISRAEL 1995 - 2004

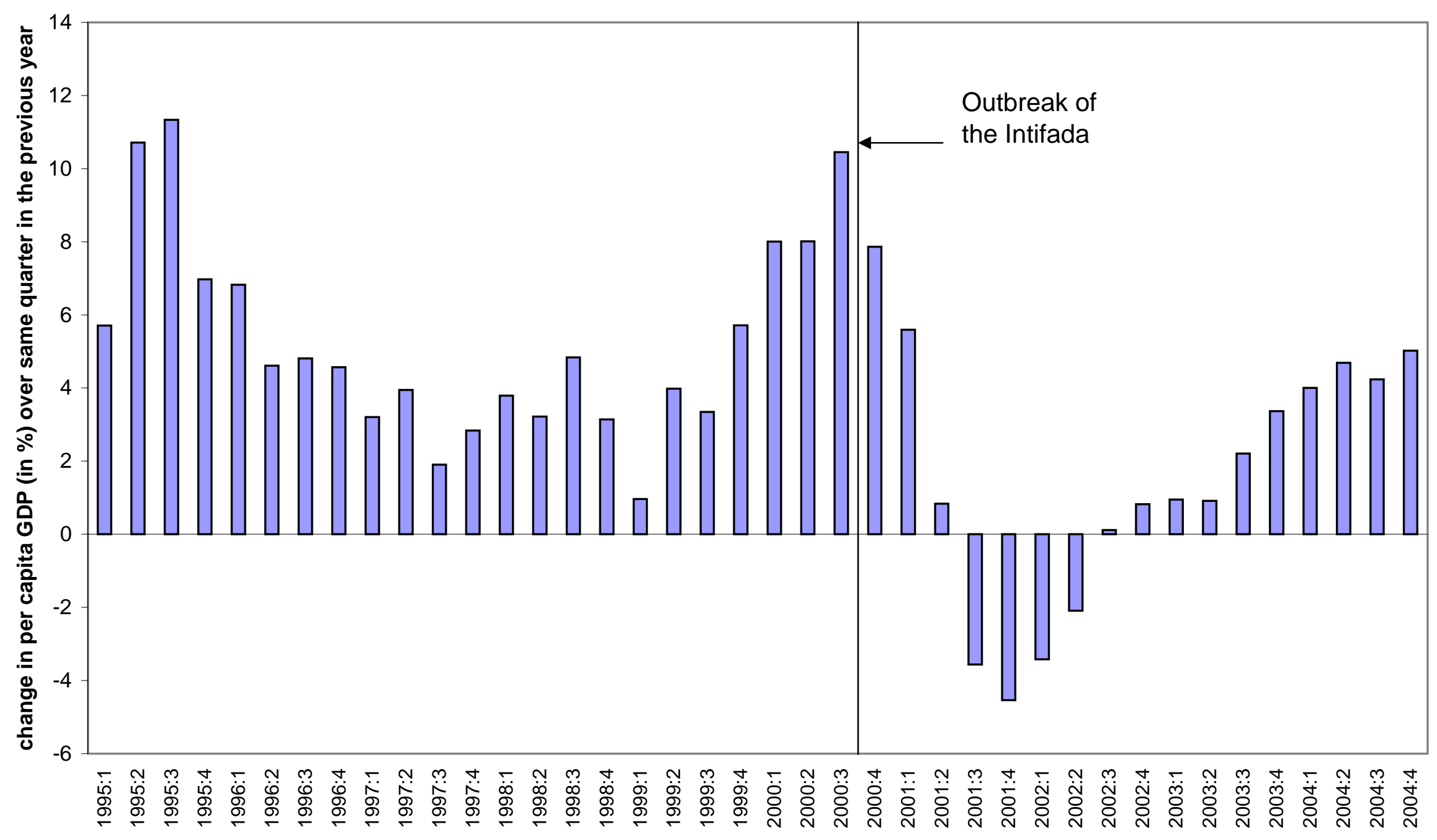

